woodlot borders a farmer's land; this contains many standing dead trees (mostly poplars.) It is a good spot to see many different species, including several varieties of woodpeckers. It is especially a favourite haunt of the Redheaded Woodpecker. Two consecutive seasons I observed these birds nesting in an old tree cavity.

Unnecessary tree-cutting continues, notwithstanding the valuable contribution made by cavity-dwellers. Scientific experiments made to provide a substitute for standing dead and dying trees appear to date to have been unsuccessful. A recent article in Audubon, by Roxanna Sayre, develops this point:

"By now it is a familiar story. First the treecutters dispatch square miles of what they like to refer to as 'over-mature' trees -and leave cavity-nesting wildlife without homes. Then wildlife scientists step in and try to create housing for squirrels, mice, birds, even bears. Nest boxes, the traditional replacement housing, aren't very attractive or long-lasting, and are vulnerable to predation.

"So a couple of U.S. Forest Service staffers in West Virginia decided to help nature provide the decaying trees in which nest holes develop. They cut live branches from healthy oaks and maples and injected them with fungal infection to induce decay. This worked - but very slowly. And it provided homes, but mainly for flying squirrels and a few white-footed mice."

Researchers then decided to use polystyrene and plant plastic trees in a forest infested with spruce budworm

"The managed area had been denuded of good nesting trees and zoologists were trying to lure woodpeckers back to the area to help subdue the plague of budworms. Holes were dug out in most of the trees but no woodpeckers nested. Apparently males couldn't attract females by tapping on the plastic trees because they would not resonate. The scientists now plan to sheath a portion of their phony trees in real plywood."'2

From the foregoing, and from the in- stances I have observed, it is evident that it is of the utmost importance that natural habitat be retained for cavitydwelling birds. Let us become more aware of this and take a greater interest in its protection and management.

PINEL, H.W. 1980. Reproductive efficiency and site attachment of Tree Swallows and Mountain Bluebirds. Blue Jay 38(3): 181 and 183.

SAYRE, ROXANNA. 1981. Creatures. Audubon 83(4): 24. Reprinted with permission from Audubon, the magazine of the National Audubon Society.

\section{GREAT BLUE HERON CONCENTRATIONS}

\section{ART J. DERKSEN, Fisheries Branch,} 1495 St. James St., Winnipeg, Manitoba. R3H OW9

On 17 May 1982, Joe O'Connor and I sighted two large flocks of Great Blue Herons feeding on dry ground. Both of us are familiar with Sandhill Cranes and are certain of the identification. Approximately 40 to 50 birds were in each flock, feeding in open fields near Powderhorn Creek, southeast of Homebrook off PR 328 and near Lake Manitoba. The fields in which the birds were feeding were used for haying and/or pasture. The flocks were within about a quarter mile of each other. The sighting was made about 1300 hours. The weather at the time was overcast, with light intermittent drizzle.

The flocks were fairly tightly knit, with several feet between individuals. They were intent on feeding and were not disturbed by the sounding of the vehicle horn.

According to William H. "Bill" Koonz, the nearest known Great Blue Heron rookeries are all about 20 miles away. 